\title{
Politeness in Estonia: A matter of fact style
}

Leelo Keevallik

\section{Book Chapter}

The self-archived postprint version of this journal article is available at Linköping University Institutional Repository (DiVA):

http:// urn.kb.se/ resolve?urn=urn:nbn:se:liu:diva-103083

N.B.: When citing this work, cite the original publication.

Keevallik, L., (2005), Politeness in Estonia: A matter of fact style. In Politeness in Europe, Leio Hickey and Miranda Stewart (eds), 203-217.

ISBN: 1853597384,1853597376

Original publication available at:

Copyright: Multilingual Matters

Publisher URL Missing 
MULTILINGUAL MATTERS SERIES

Series Editor: Professor John Edwards,

St. Francis Xavier University, Antigonish, Nova Scotia, Canada

Other Books in the Series

Beyond Boundaries: Language and Identity in Contemporary Europe

Paul Gubbins and Mike Holt (eds)

Bilingualism: Beyond Basic Principles

Yean-Marc Dewaele, Alex Housen and Li Wei (eds)

Can Threatened Languages be Saved?

Joshua Fishman (ed.)

A Dynamic Model of Multilingualism

Philip Herdina and Ulrike Jessner

English in Africa: After the Cold War

Alanin M. Mazrui

Identity, Insecurity and Image: France and Language

Dennis Ager

Ideology and Image: Britain and Language

Dennis Ager

Jewish Sociolinguistics: Towards a Synthesis John Myhill

Language and Society in a Changing Italy Arturo Tosi

Linguistic Minorities in Central and Eastern Europe Christina Bratt Paulston and Donald Peckham (eds)

Maintaining a Minority Language

Joln Gibbons and Elizabeth Ramirez

Motivation in Langtuage Planning and Language Policy Dennis Ager

Multilingualism in Spain

M. Teresa Turell (ed.)

Quebec's Aboriginal Languages

Jacques Maurais (ed.)

The Other Languages of Europe

Guus Extra and Durk Gorter (eds)

Where East Looks West: Success in English in Goa and on the Konkan Coas Dennis Kurzon

Other Books of Interest

Language, Culture and Communication in Contemporary Europe Charlotte Hoffman (ed.)

Language, Discourse and Borders in the Yugoslav Successor States Birgitta Busch and Helen Kelly-Hoines (eds

Medium or Message? Language and Faith in Ethnic Churches Anya Woods

Negotiating of Identities in Multilingual Contexts

Aneta Pavlenko and Adrian Blackledge (eds)

Understanding Deaf Culture: In Search of Deafhood

Paddy Ladd

Please contact us for the latest book information:

Multilingual Matters, Frankfurf Lodge, Clevedon Hall

Victoria Road, Clevedon, BS21 7HH, England

http://www.multilingual-matters.com
MULTILINGUAL MATTERS 127

Series Editor: John Edwards

\section{Politeness in Europe}

\author{
Edited by \\ Leo Hickey and Miranda Stewart
}

MULTILINGUAL MATTERS LTD

Clevedon $\cdot$ Buffalo $\cdot$ Toronto 


\section{Contents}

Notes on the Contributors $\ldots \ldots \ldots \ldots \ldots \ldots \ldots \ldots \ldots \ldots$ vir

Introduction

Leo Hickey and Miranda Stewart $\ldots \ldots \ldots \ldots \ldots \ldots \ldots \ldots \ldots$

Western Europe

1 Politeness in Germany: Politeness in Germany?

Juliane House . . . . . . . . . . . . . . . . . . . . . . . . . . . . . 13

2 Politeness in France: How to Buy Bread Politely

Catherine Kerbrat-Orecchioni . . ................... 29

3 Politeness in Belgium: Face, Distance and Sincerity in

Service-exchange Rituals

Emmanuelle Danblon, Bernard de Clerck and Jean-Pierre van Noppen . . 45

Library of Congress Cataloging in Publication Data

Politeness in Europe/Edited by Leo Hickey and Miranda Stewart.

Multilingual Matters: 127)

Includes bibliographical references and index.

1. Sociolinguistics-Europe. 2. Etiquette-Europe. I. Hickey, Leo. II. Stewart, Miranda.

III. Series

P40.5.E752E856 2004

$306.44094-\mathrm{dc} 22$

2003024120

British Library Cataloguing in Publication Data

A catalogue entry for this book is available from the British Library.

ISBN 1-85359-738-4 (hbk)

ISBN 1-85359-737-6 (pbk)

\section{Multilingual Matters Ltd}

UK: Frankfurt Lodge, Clevedon Hall, Victoria Road, Clevedon BS21 7HH

USA: UTP, 2250 Military Road, Tonawanda, NY 14150, USA.

Canada: UTP, 5201 Dufferin Street, North York, Ontario M3H 5T8, Canada.

Copyright $\odot 2005$ Leo Hickey, Miranda Stewart and the authors of individual chapters.

All rights reserved. No part of this work may be reproduced in any form or by any means without permission in writing from the publisher.

Typeset by Patrick Armstrong Book Production Services.

Printed and bound in Great Britain by the Cromwell Press Ltd.

4 Politeness in Luxemburg: Greetings from Foreign Parts

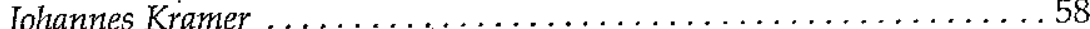

5 Politeness in The Netherlands: Indirect Requests

Rob le Pair ...............................66

6 Politeness in Austria: Politeness and Impoliteness

Silvia Haumann, Ursula Koch and Karl Sornig . . . . . . . . . . . 82

7 Politeness in Switzerland: Between Respect and Acceptance

Guiseppe Manno ........................... 100

8 Politeness in Britain: 'It's Only a Suggestion...'

Miranda Stewart .......................... 116

9 Politeness in Ireland: '... In Ireland, It's Done Without Being Said'

Jeffrey L. Kallen ............................ 130

Northern Europe

10 Politeness in Norway: How Can You Be Polite and Sincere? Thorstein Fretheim ............................... 145

11 Politeness in Denmark: Getting to the Point Elin Fredsted . . . . . . . . . . . . . . . . . . . . . . . . . . . . . 159

12 Politeness in Sweden: Parliamentary Forms of Address Cornelia Ilie . . . . . . . . . . . . . . . . . . . . 174

13 Politeness in Finland: Evasion at All Costs Valma Yli-Vakkuri......................... 189 


\section{Notes}

1. The Finnish term for politeness, kohteliaisuus (n.), kohtelias (a.), however, is derived from the verb, kohdella (to treat).

2. Finnish has special verbs for the use of 2.sg. and 2.pl., derived from the respective pronouns, which are impossible to translate, as English uses the same pronoun in both cases.

\section{Reference}

Yli-Vakkuri, V. (1987) Aspect and the affective attitude of the speaker: Usage and meaning in grammatical case variation in Finnish. In M. Koski et al. (eds) Fennistica Festiva in Honorem Göran Karlsson Septuagenaria (pp. 189-205). Åbo: Åbo Akademisförlag

Yli-Vakkuri, V. (1989) Suomalaisen puhuttelun piirteitä. (Features of address in Finnish.) In A. Kauppinen et al, V. Yli-Vakkuri and K. Kylliki (eds) Äidinkielenopettajain liiton vuosikirja XXXVI (The 36th Year Book of the Association of Teachers of Finnish as the Mother Tongue) (pp. $43-74$ ). Helsinki: Association of Teachers of Finnish as the Mother Tongue.

\section{Chapter 14}

\section{Politeness in Estonia: A Matter of Fact Style}

\section{LEELO KEEVALLIK}

\section{Introduction}

Linguistic politeness is intimately connected with social norms. Estonian society has gone through considerable change over the last ten years. It has regained independence and, at the same time, switched from a planned to a market economy as well as from dictatorship to democracy. A decade is most probably not long enough for linguistic norms to change drastically: as we know, the structure of a language often takes much longer to change. Politeness, however, may to some extent be subject to deliberate influence, as witnessed, for example, by the reform of Swedish $d u$ (you, sg.) where the recommendations of some left-wing organisations on the usage of mutual $d u$ (T) have won general social acceptance (Paulston, 1976: 365-66). It is, thus, not unlikely that change is taking place in Estonian politeness at present.

Several new phenomena connected with the market economy have had a relatively direct impact on patterns of politeness. It is widely known that marketing was unnecessary in the planned economy and service was nonexistent. Due to the general shortage of goods, clients were treated as if the sellers were doing them a favour. Therefore, there was no need for selling strategies to be developed or for shop assistants to be trained to behave politely. During the last ten years, western-style service and marketing programmes have gained in popularity and although Estonian tourist brochures still warn westerners not to expect $h i$ and thank you (not to mention how are you?) in shops in Estonia, change in service culture has been inevitable, at least at local level.

Another change has been towards informality throughout society, particularly in the media. The media had been under close scrutiny by the Soviet authorities and a special very formal style had evolved in reports on political, economic and other sensitive matters. This style has now disappeared along with strict political censorship. Also gone are the previously common language editors whose main task was to eliminate 
anything not in accordance with the established language standard. Less normative and more democratic language use in the media has resulted in numerous outcries by the general public and even by some linguists concerning the vanishing knowledge of 'correct language'. The current more informal style of public language use has meant that especially the older generations may sometimes feel that they are not being treated politely.

Regardless of these changes towards what could be seen as a more involved style (see later), Estonians are still quite reserved. We will first look at address forms and strategies, mainly attending to positive face (use of first names, compliments). Then we shall consider more elaborate negative face strategies: commanding and requesting. Our definition of politeness is consequently broader than the use of explicit linguistic indirectiness and is, in part, due to the nature of our data.

\section{The Data}

Our corpus consists of 324 naturally-occurring telephone conversations of two types: telemarketing calls from one of the biggest daily newspapers in Estonia (109 conversations), and everyday calls between family members, relatives, friends and colleagues, recorded at the informants homes. The corpus comprises more than 10 hours of conversational language (about 103,000 words) and includes representatives of both sexes and all ages, although there is somewhat more data from younger females who were our primary informants.

The majority of the data is informal. Everyday conversations comprise about two-thirds of the corpus data in terms of time (about 6.5 hours) and the telemarketing calls are not particularly formal. Telemarketing reached Estonia with re-independence and at the time of the recordings (1997/98), the sellers were doing their job on an intuitive basis - the informants of this study had no training whatsoever. There is no flattering or pushiness, no aggressive tactics. There are no scripts involved. Sometimes the telemarketers even feel free to argue with their clients' opinions. Consequently, the corpus should provide a relatively good basis for politeness research in Estonian as practised by ordinary people in everyday settings.

\section{Singular and Plural Address}

Address is a sensitive way of expressing social relations between interlocutors, as perceived by themselves. In Estonian speech, it is possible to address a person using either 2.sg. (T) or 2.pl. (V), the latter being more formal. The system involves the pronouns (sina/sa you, sg., teie/te you, pl.) as well as the respective verbal suffixes.
It seems that, at present, usage of $\mathrm{T}$ and $\mathrm{V}$ is symmetrical: parents are not addressed as $\mathrm{V}$ by children, let alone elder brothers, and grandparents receive $\mathrm{V}$ extremely rarely. Doctors, lawyers and professors do not automatically have the right to address their inferiors as T. Shop assistants and waiters are typically addressed as $\mathrm{V}$, as are the representatives of 'lower' occupations such as cleaners and maintenance workers. In the adult world the unmarked variant is $V$, which is mutually used until the parties agree upon $\mathrm{T}$. The right to initiate $\mathrm{T}$, however, is supposed to be granted according to power relations, i.e. the older and/or higher status (female) speaker can suggest mutual $\mathrm{T}$.

There may be a correlation between type of society and symmetry of address usage. Brown and Gilman (1960: 257-261) had already observed that in several European cultures the power dimension was losing ground as far as the usage of different address pronouns was concerned, and that in egalitarian societies $\mathrm{T}$ and $\mathrm{V}$ were used instead for marking intimacy/distance and informality/formality with symmetrical address patterns prevailing, and asymmetrical patterns disappearing. It is hard to know whether there has been any such change in Estonia - we now live in a democracy but society has actually become more differentiated economically during re-independence However, according to one judgement from the end of the 1980s, asymmetrical address was still 'disturbingly common' back then and was even propagated on TV and radio (Erelt, 1990: 37).

A traditional and still surviving domain of asymmetrical usage is between children and adults. For example, at school the degree of acquaintance between teachers and students should usually require mutual $\mathrm{T}$; however, while teachers generally use $\mathrm{T}$ at least until high school, the students are expected to use V.

Singular and plural address patterns have been studied by means of a questionnaire to 8-9, 14-15, and 17-18-year-old informants (Keevallik, 1999). This demonstrated that even these young people choose address forms more on the basis of solidarity judgements (degree of acquaintance) than the hierarchical dimension of power. They would, for example, use $T$ with higher-ranking officials if they knew them personally.

Among other influential factors was area of residence, i.e. whether the informant lived in the city or the countryside. Interestingly, the smaller the settlement was, the more the students preferred to hear $\mathrm{T}$ from their teachers and to respond similarly. In the capital Tallinn, the oldest students expected considerably more mutual $V$ than in the rural township of Kadrina ( $40 \%$ and $10 \%$ respectively wanted the teachers to use V, 36\% and $65 \%$ respectively wanted to use $\mathrm{T}$ themselves to the teacher, [Keevallik, 1999: 135-36]). These results are not counterintuitive if we consider that 
social networks tend to involve more multiple ties in smaller places (Malmberg \& Nordberg, 1994).

The Estonian second-person address system is rigid: once a pattern is established between two people, it is likely to persist. As one informant put it, he would never use $V$ to his classmates even if one of them became the President of the Republic. The established pattern can only be temporarily changed for strategic reasons, e.g. a teacher who wants to express irony towards an inattentive student may say Kas ma vôiksin teid segada? (May I disturb you: pl?). A marked $\mathrm{T}$ may be used to be derogatory or express anger towards somebody usually addressed as $\mathrm{V}$ (the teacher). This contrasts with, for example, Russian usage of $\mathrm{T}$ and $\mathrm{V}$ where much more dynamic switches have been reported (Friedrich, 1972: 288-98).

In accordance with the trend towards informality in the Estonian speech community, universal $\mathrm{T}$ seems to be spreading (for a journalistic account, see Laanem, 1999). At university, symmetrical $\mathrm{T}$ may be used between students and younger teachers. The new corporate culture also apparently involves addressing every insider as T, a pattern that is unfamiliar and sometimes uncomfortable for the older generation. The spread of $\mathrm{T}$ may be supported by the two most popular foreign languages at the moment Finnish and English, that only have one address pronoun (as opposed to Russian, the previously most common second language). Even if younger people are certainly leading the shift to $T$, informants in our study generally rejected the possibility of eliminating $V$ altogether. Many said that they wanted 'politeness to be preserved' in society, they wanted to be able to express deference and receive respectful $V$ themselves. $V$ also seems to be a handy means of keeping unpleasant people (amongst them teachers) at a safe distance.

In addition to second-person address, there are some fixed address patterns in third-person singular involving the respectful titles proua (Mrs), preili (Miss), and härra (Mr). These forms can mostly be encountered in service situations: Kas proua soovib teed vōi kohvi? (Does Madam want tea or coffee?). At present they are experienced as new due to the overtly unfavourable attitude towards them during Soviet times, when official attempts were made to introduce the solidary seltsimees (comrade) instead. According to Braun's (1988: 57-61) hypothesis about the universal tendency of polite forms to recede, these expressions may appear especially polite because of their relative novelty.

\section{First Names and Personal Reference}

Cultures differ in the frequency of usage of names. In Estonian, they are certainly used less often than in the American or Swedish speech communities. First, identification sequences on the phone rarely involve names. In our corpus, institutional callers and answerers only introduced themselves by first and/or second name 24 times (out of about 150). Instead, merely the name of the company, newspaper, etc. was used. Rääbis' study (2000) on a different corpus confirms this result. She also notes that private persons do not usually introduce themselves when calling institutions if they do not expect to be recognised by the representative (Rääbis, 2000: 413-14). In private homes, however, in our corpus, 39 answerers gave their names as a response to the call, 29 of them first names (out of about 250).

More interestingly, the construction tere (hi) + first name was used altogether 60 times. The use of the interlocutor's first name can be seen as a means of satisfying positive face wants, especially when it involves recognition of the other (Brown \& Levinson, 1987: 38; Schegloff; $; 1979 ; 1986$ ) This is the place in Estonian conversations where positive face can quite regularly be attended to. In Example 1, neither of two friends gives her name but they both express recognition of the other by name.

\section{Example 1}

1 M: halloo (hello)

2 L: tere Merilin (hi Merilin)

3 M: tere Liina (hi Liina)

Outside the opening sequence, names were hardly used. In the telemarketing calls, the name of the (potential) client was never used outside the identification sequences. This is certainly unusual in comparison with many other western cultures where (first) names are very often used manipulatively in this type of encounter. In American society, even young children are able to use names as mitigators (Ervin-Tripp et al., 1990: 326, 329). Swedish children are socialised from the very beginning to add the name to tack (thanks), e.g. tack Klara. Unfortunately, there are no comparative quantitative data available but 21 cases in 10 hours of this corpus does not seem to be a high frequency. First names may occasionally precede requests, as in Example 2.

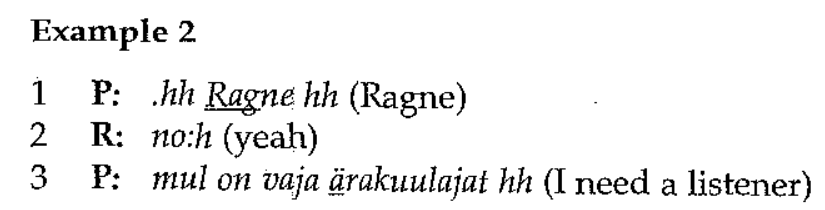

Furthermore, when talking about closely related third persons, names are used sparingly. Parents and grandparents are called by their names 
extremely rarely and are mostly referred to with kinship terms, e.g. 'your mother'. Even children are often referred to as e.g. 'my child' rather than by name. Direct reference to those present may be avoided altogether by using first-person plural, impersonal or generic forms (Erelt, 1990). For example, after surrendering to her friend's insistence on going out late at night, a girl says: ahh jumal jumal vana inimene aetakse välja (oh god, an old person is forced to go out) jokingly referring to herself as an 'old person'. By using the impersonal form of aetakse (force, drive: impersonal), she avoids putting the blame explicitly on her friend. Reference avoidance is supposedly very frequent, similar to what happens in Finnish (Hakulinen, 1987). We could thus conclude that positive face is not primarily attended to via reference in Estonia.

\section{Openings and Closings}

Conversational openings and closings can allow ritual exchange of polite formulas. What appears to be most striking in Estonian openings and closings is their brevity. According to Schegloff (1986: 129-30), we would normally find 'how-are-you' sequences in American phone-call openings. In Estonian openings these are rare. Furthermore, they are usually not reciprocal as they are in America (Rääbis, 2000: 418). The greeting does not always have to be returned either, especially between close acquaintances. In Example 3, there is no space provided for the immediate return of the greeting - the caller Ene continues her turn by introducing herself. This is acknowledged with the particle $j a h$, which is a mere go-ahead for the caller to give her reason for calling.

\section{Example 3}

1 A: Aili kuuleb (Aili listening)

2 E: tere Aili Ene siin (hi Aili, Ene here)

3 A: jah (yeah)

4 E: kudas teil läks täna (how did it go today)

Like the openings, Estonian conversation closures may be very brief. Terminating an informal conversation in Estonian does not usually involve numerous good wishes and greetings to relatives (in comparison with Sweden, where sending greetings to each other's intimates is a norm). The difference from the American closures seems to be that goodbyes need not be reciprocal or even present (see Example 4, cf. Schegloff \& Sacks, 1973).

\section{Example 4}

1 T: siis me:: saame kokku onju (we'll meet then, won't we)

\section{O: okei (okay) \\ 3 T: okei (okay) \\ 4 O: tšau (bye)}

In many cultures, emotional 'presents' can conventionally be made to the interlocutor during the closings. In contrast, a short opening and closure are indications of intimacy in Estonian calls, while institutional calls tend to end with good wishes.

\section{Complimenting}

Attending to the positive face of the interlocutor is probably not prevalent in Estonian, just as in Finland (Saari, 1990, 1995). Speakers feel embarrassed about close interest in personal topics, exaggerated emotions and praise. Even if all Brown and Levinson's positive politeness strategies are represented, e.g. in marketing encounters with trained informants (Vellerind, 2000), they are certainly not as dominant as in, for example, the Swedish or American speech communities.

On the basis of our corpus, we can suggest that complimenting is a rare and not especially elaborate activity among Estonian interactants. The corpus involves 11 cases, many of them consisting of only one word, e.g. tubli, approximately 'brave, good'. Even if it is possible to accept a compliment with a aitäh or tänan (thank you), it only happens once in the corpus. In two cases the content is explicitly denied, which is what researchers have noticed even in other cultures (Pomerantz, 1978). Most often, however, the praise goes unacknowledged, i.e. the receiver of the compliment changes the topic. Apart from our corpus, which may not be representative in terms of compliments, Estonians who have been interacting in cultures more oriented towards positive face have reported uneasiness with compliments.

There are other research results pointing in the same direction Estonians are not good at getting verbally involved. Compared to Canadians, Estonians have been shown to be less likely to initiate conversations, attribute negative characteristics to untalkative people, and feel uncomfortable with silences in conversations (Kivik, 1998: 76). Talkativeness is the negatively-evaluated target of numerous proverbs (Heinsoo, 1999). Estonian mothers prompt children's conversational participation less often than Swedish and American mothers do from the age of two to their teens (Junefelt \& Tulviste, 1997; 1998; Tulviste, 1998). There are thus many indications that Estonians are verbally quite reserved. 


\section{Commands and Requests}

Explicitly targeting negative face needs seems more frequent in our corpus (and in the Estonian speech community) and is evident in cases where one interlocutor wants the other to do something - acts that have been called intrinsic FTAs (Brown \& Levinson, 1987: 65-8).

It is not easy to distinguish between commands and requests in conversational data since the difference mostly appears to be in the degree of politeness. As already noted by Brown and Levinson (1987: 94-101), direct imperatives are used mainly in activities that are urgent or where the recipient is in some way a beneficiary (e.g. oota korra [wait a second], võta nii palju kui tahad [take as much as you like]). In addition, commands to third persons are not necessarily modified for politeness, e.g. las ta elistab siis Enele kui ta tuleb (let him call Ene when he comes) (las is a particle that is, among other things, used for giving mediated orders), especially when the imposition on the interlocutor is small.

At the other end of the continuum, there are off-record strategies where the command/request is only implicated. For example, when the speaker wants to talk to someone other than the person on the phone, she may say siis ma räägin Nelega oma jutud ära (I'll talk to Nele then), which implicates that the present interlocutor has to go and get Nele - there is no other way for the content of this statement to become true. The implicit request is expressed in the form of a statement about what the speaker is planning to do, namely to speak to Nele.

Another implicit way of making a request is to produce a statement about some shortcoming of the speaker herself. In the following Example 5, a request for information is carried out in the form of a statement. The speaker, who is supposed to be on his way to his interlocutor, claims that he does not know the address.

\section{Example 5}

1 H: [ee ee] tähendab e me ei tea ju kus te elate (you know, we don't know where you live)

2 K: aa (0.2) Ranniku neliteist seitsekend kaks (oh, Ranniku fourteen seventy two

In this example, the first word of H's turn is the formulation particle tähendab, (approximately. 'you know'), which may foreshadow something face-threatening to follow. Furthermore, the particle $j u$ indicates that according to $\mathrm{H}$ this piece of information is not new to the interlocutor, i.e. that $\mathrm{K}$ is aware that his address is unknown to $\mathrm{H}$. This clearly implicates that it is $\mathrm{K}^{\prime}$ s duty to provide the necessary information, which he does immediately in the next turn.
Another way to make a request off-record is to ask about the prerequisites of request compliance. For example, when the caller wants somebody else on the phone, she may ask whether the person is present, rather than actually carrying out the FTA (see Example 6).

\section{Example 6}

1 M: tere ega Helenit ei ole (hi, isn't Helen [there])

2 O: jaa kohe (yes, one moment)

Naturally, this way of asking for a third person is conventionalised and the question about somebody's presence is usually not treated as a question. In this example, $\mathrm{O}$ promises to fetch Helen without actually answering the question (jaa 'yes' is not a grammatically appropriate answer here). The speech act in line 1 is clearly interpreted via a conversational implicature.

Most interestingly, however, when working with interactional data, we notice that potential FTAs are rarely carried out in one step. FTAs need not even be carried out by the same speaker. As has been shown in conversation-analytic work, awkward interactional steps may be preceded by the so-called pre-sequences (e.g. Schegloff, 1980; 1988). In the case of requests, they may be used for checking whether the prerequisites for the request are fulfilled (the question about Helen's presence in Example 6 can also be seen as the initiation of a pre-sequence). Pre-sequences come into being because of face concerns - they allow the off-record negotiation of business with face' implications well in advance of the possible on-record transaction (Brown \& Levinson, 1987: 40). The recipient is politely given the possibility of resigning without being directly confronted with an unwelcome offer, request etc. Thus, what in speech act theory we would see as one single act may actually be a series of actions and still recognizable by the interactors as, for example, doing requesting.

We have evidence that the interlocutor often already understands during the pre-sequence that a request or a proposal is due. In Example 7, K pursues M's plans for the evening. At first, $\mathrm{M}$ misinterprets $\mathrm{K}^{\prime} \mathrm{s}$ question as being about the present moment and $\mathrm{K}$ has to put it more precisely. In line 4, $\mathrm{M}$ answers that she will be at Püve (a street address) for some time. Asking about interlocutor's plans may function as a pre-sequence for a request or a proposal and it is probably recognisable as such by $\mathrm{M}$ after line 3. However, when $K$ proceeds to ask about the exact time of M's stay at Piive, $\mathrm{M}$ can already guess that a request is to come. 


\section{Example 7}

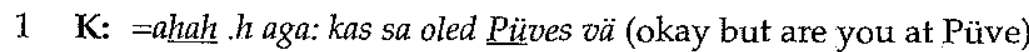

2 M: ei ma olen siin töö juures @ (no, I'm here at work)

3 K: ei kuidas su plaanid on öhtuks (no, what are your plans for tonight)

4 M: ööö jaa ma mingi ajani olen Püves jah (yes, I'll be at Püve for sometime)

5 K: mingi ajan (for some time)

6 M: jah (yes)

7 K: [mis (su)] (what)

8 M: [tahad] oäroimist (you want dyeing)

9 . K: tahaksin küll jaa (l would, yes)

In Example 7, we can see how a request sequence is formed in collaboration between the interlocutors. Even if it is one of them who actually wants a favour (her hair dyed), the receiver of the request is the one who actually utters it in line 8 . The pre-sequence has thus made it clear to the receiver that a request is to follow and instead of letting $K$ do the FTA she almost turns it into an offer, which is a preferable action (Brown \& Levinson, 1987: 38; Heritage, 1984; Levinson, 1983: 307-08; 332-45). At the same time, it is still a mere guess at what $\mathrm{K}$ wants and $\mathrm{K}$ has to confirm it, which she does in line 9. The confirmation is done in the conditional form, which could be seen as a grammatical mitigating device for requests in general. Only after the confirmation can the request be seen as carried out. It is the joint action of the interlocutors that eventually results in a request for hair to be dyed.

Speech act theory and politeness theory, however, enforce a sentencebased speaker-centered mode of analysis. When working with conversational data from everyday interaction, it seems inevitable to use a methodology enabling us to account for the real-time emergence of the patterns. Apart from requests which are transformed into offers, parts of what we could consider to be requesting activity can occur after the request has been complied with, especially hedges and attending to positive face. Consider Example 8 where a compliment follows M's affirmation that she can lend an article to $L$ (see appendix for transcript conventions).

\section{Example 8}

1 L: jasa saad <@ selle mulle@anda onju=@> (and you can give it to me, can't you)

2 M: =saan (yeah)

3 L: sa oled nii musi (you are such a sweetie)
In order to incorporate sequences into their model, Brown and Levinson (1987: 233) suggest that politeness should be understood as a higher level intention, in fact, the reason why these sequences are designed in this particular way. That is what the common-sense scope of politeness is and several researchers have also claimed that politeness is simply a means of reaffirming and strengthening relationships (Bayraktaroglu, 1991: 5; Holmes, 1995; Lakoff, 1973: 298). At the same time, in Brown and Levinson's model, positive and negative politeness are almost exclusively reduced to indirectness strategies striving against the cooperation principle in the case of FTAs (for similar points, see Held, 1992: 131; Meier, 1995). Thus, politeness is, according to them, a technical concept applying to acts with inherent potential for conflict and which, furthermore, presupposes constant awareness of the most efficient ways of saying things.

If politeness were a higher-ranking (social) principle, we should not take the different linguistic expressions as a starting point for the model of politeness, as Brown and Levinson do. Rather, we should keep the social and the lingustic levels of analysis apart by talking about negative and positive face needs as opposed to various (linguistic) strategies used to satisfy these needs. Among other things, not committing the FTA by remaining silent can target either the positive or the negative face (Sifianou, 1995: 107) and off-record strategies are often likely to be used to attend to negative face needs.

This does not mean that it is not possible to note explicit linguistic strategies that are often used specifically, for example, in order to maintain the negative face of the interlocutor, such as avoidance of imperatives by using (as directives) conditionals, negations and questions in Anglo-Saxon cultures (Wierzbicka, 1985). Politeness, however, could probably be treated as an omnipresent aspect of all social activities, so that everything done and said will be experienced as either to some or other degree polite, impolite or as quite neutral in a particular culture (Sell, 1992: 114). Seeing politeness as adequacy for the situation (e.g. Braun, 1988: 49) or appropriateness (Meier, 1995: 390) would also be in better accordance with our commonsense usage of the word.

\section{Conclusion}

The classic way of treating politeness phenomena in linguistics might not be the best way to handle conversational data, since what might have been considered single speech acts may actually be better accounted for as a series of conversational steps. Brown and Levinson's influential model of politeness seems to capture politeness in a single calculation on the basis of a couple of stable variables. Dissatisfaction with this view has resulted in 
attempts to make the model more dynamic and account for extended discourse (e.g. the interactional imbalance view of natural conversations by Bayraktaroğlu, [1991]; the constantly renegotiable conversational contract by Fraser [1990], Fraser and Nolen, [1981]; or work on literary dialogue by Buck, [1997]). Looking more closely at the mechanisms of conversation may reveal new facets of politeness. As Heritage (1984: 265) puts it, there is a general bias intrinsic to many aspects of the organisation of talk which is favourable to the maintenance of bonds of solidarity between actors and which promotes the avoidance of conflict. Face wants are a generative mechanism of human interaction and this is reflected in conversation.

In an attempt to generalise and interpret the above results on Estonian, we could say that the interlocutors do not seem to attend very much to face needs. Positive face is not attended to as frequently as in several adjacent cultures and caring about each other is implicit rather than actively expressed. Estonians are somewhat more oriented toward negative face but directness may be tolerated to quite an extent. For example, the preferred utterance type of Estonians for regulating children's attention and physical activity is the imperative (Tulviste, 1995). Intuitively, the results of certain quantitative comparative studies into German could apply to Estonian: Germans use higher levels of directness in complaints and requests compared to speakers of English (House \& Kasper, 1981: 159-166), and fewer phatic utterances in personal relationships compared to speakers of Greek (Pavlidou, 1994: 507). Like the Germans in Pavlidou's study, Estonians seem to focus more on content than relationships in communication. Directness need not be offensive or impolite. Considering the length of German occupation and presence on Estonian territory, it would not be too surprising if politeness patterns were similar.

Interestingly, Giles et al. (1992: 220) have concluded that there are differences in conversational style between East and West - Westerners talk for affiliative purposes, and in order to fill silences which are deemed stressful, while Easterners talk primarily for instrumental purposes and can remain in comfortable silence in other cases. If this crude generalization is true, in terms of communicative patterns, Estonia still seems to belong to the East.

\section{Appendix:}

\section{Transcription conventions}

$\begin{array}{lll}\text { underlining } & - & \text { main stress } \\ \text { h(h) } & - & \text { in-breath } \\ \text { hh } & - & \begin{array}{l}\text { out-breath } \\ \text { lengthening }\end{array} \\ : & - & \text { overlap } \\ {[x \times x]} & - & \text { length of pause } \\ (0.2) & - & \text { laughter syllable } \\ @ & - & \text { the stretch of talk produced with a 'smiling voice' }\end{array}$

\section{References}

Bayraktaroğlu, A. (1991) Politeness and interactional imbalance. The International Journal of the Sociology of Language 92, 5-34.

Braun, F. (1988) Terms of Address: Problems of Patterns and Usage in Various Languages and Cultures. (Contributions to the Sociology of Language, 50). Berlin, New York Amsterdam: Mouton de Gruyter.

Brown, P. and Levinson, S. (1987) Politeness: Some Universals in Language Usage. Cambridge: Cambridge University Press.

Brown, R. and Gilman, A. (1960) The pronouns of power and solidarity. In T.A. Sebeok (ed.) Style in Language (pp. 253-76). Cambridge, MA: Technology Press of MIT.

Buck, R. A. (1997) Towards an extended theory of face action: Analyzing dialogue in E. M. Foster's A Passage to India. Journal of Pragmatics 27 (1), 83-106.

Erelt, M. (1990) Kóneleja ja kuulaja kaudse väljendamise võimalusi eesti keeles. (The possibilities of expressing the speaker and the listener in an indirect way in Estonian). Keel ja Kirjandiss 38 (1), 35-9.

Ervin-Tripp, S., Gu, Y. and Lampert, M. (1990) Politeness and persuasion in children's control acts. Journal of Pragmatics 14 (2), 307-31.

Fraser, B. (1990) Perspectives on politeness. Journal of Pragmatics 14 (2), 219-36.

Fraser, B. and Nolen, W. (1981) The association of deference with linguistic form. The International Journal of the Sociology of Language 27, 93-109.

Friedrich, P. (1972) Social context and semantic feature: The Russian pronominal usage. In J.J. Gumperz and D. Hymes (eds) Directions in Sociolinguistics: The Ethnography of Communication (pp. 270-300). New York: Holt, Rinehart and Winston.

Giles, H., Coupland, N. and Wiemann, J. (1992) 'Talk is cheap...' but 'My word is my bond': Beliefs about talk. In K. Bolton and H. Kwok (eds) Sociolinguistics Today: International Perspectives (pp. 218-41). London \& New York: Routledge.

Hakulinen, A. (1987) Avoiding personal reference in Finnish. In J. Verschueren and M. Bertuccelli-Papi (eds) The Pragmatic Perspective: Selected Papers from the 1985 International Pragmatics Conference (pp. 141-53). Amsterdam, Philadelphia: John Benjamins. 
Heinsoo, H. (1999) Talkative as a Finn or an Estonian? In A. Künnap (ed.) IndoEuropean-Uralic-Siberian Linguistic and Cultural Contacts. Fenno-ugristica 22 (pp. 77-84). Tartu: Department of Uralic Languages, University of Tartu.

Held, G. (1992) Politeness in linguistic research. In R.J. Watts, S. Ide and K. Ehlich (eds) Politeness in Language: Studies in its History, Theory and Practice, Trends in Linguistics. Studies and Monographs 59 (pp. 131-53). Berlin, New York: Mouton. de Gruyter.

Heritage, J. (1984) Garfinkel and Ethnomethodology. Cambridge: Polity Press.

Holmes, J. (1995) Women, Men and Politeness. London, New York: Longman.

House, J. and Kasper, G. (1981) Politeness markers in English and German. In F. Coulmas (ed.) Conversational Routine: Explorations in Standardized Communication Situations and Prepatterned Speech (pp. 157-85). The Hague, Paris, New York: Mouton Publishers.

Junefelt, K. and Tulviste, T. (1997) Regulation and praise in American, Estonian, and Swedish mother-child interaction. Mind, Culture, and Activity: An International Journal 4 (1), 24-33.

Junefelt, K. and Tulviste, T. (1998) American, Estonian and Swedish mothers' regulation of their children's discourse construction. In M. de Lyra and J. Valsiner (eds) Construction of Psychological Processes in Interpersonal Communication (pp. 137-54). Stanford, CA: Ablex.

Keevallik, L. (1999) The use and abuse of singular and plural address forms in Estonian. International Journal of the Sociology of Language 139, 125-44.

Kivik, P.-K. (1998) What silence says: Communicative style and identity. Trames 2 (1), 66-90.

Laanem, T. (1999) Sinatamine tikub eestlaste kõnepruuki. (Saying sina 'you: 2sg.' is spreading among Estonians), Eesti Päevaleht 14. August, 14.

Lakoff, R. T. (1973) The logic of politeness; or minding your p's and q's. In Papers From the Ninth Regional Meeting of the Chicago Linguistic Society (pp. 292-305). Chicago: Department of Linguistics, University of Chicago.

Levinson, S. (1983) Pragmatics. Cambridge: Cambridge University Press.

Malmberg, A. and Nordberg, B. (1994) Language use in rural and urban settings. In B. Nordberg (ed.) The Sociolinguistics of Urbanization: The Case of the Nordic Countries (pp. 16-50). Berlin, New York: Walter de Gruyter.

Meier, A. J. (1995) Passages of politeness. Journal of Pragmatics 24 (4), 381-92.

Paulston, C. B. (1976) Pronouns of address in Swedish: Social class semantics and a changing system. Language in Society 5 (3), 359-386.

Pavlidou, T. (1994) Contrasting German-Greek politeness and the consequences. Journal of Pragmatics 21 (5), 487-511.

Pomerantz, A. (1978) Compliment responses: Notes on the co-operation of multiple constraints. In J. Schenkein (ed.) Studies in the Organization of Conversational Interaction (pp. 79-112). New York: Academic Press.

Rääbis, A. (2000) Telefonivestluse sissejuhatus. (Phone conversation opening). Keel ja Kirjandus 48 (6), 409-18.

Saari, M. (1990) Interaktionsstrategier i Helsingfors. (Interaction strategies in
Helsinki]). In K. L. Berge and U.-B Kotsinas (eds) Storstadsspråk och storstadskultur $i$ Norden (Meddelanden från Institutionen för nordiska språk vid Stockholms universitet 34). (pp. 200-12). Stockholm: Stockholms Universitet.

Saari, M. (1995) Synpunkter på svenskt språkbruk i Sverige och Finland. (Views on the usage of Swedish in Sweden and Finland) Folkmalsstudier 36, 75-108.

Schegloff, E. A. (1979) Identification and recognition in telephone conversation openings. In G. Psathas (ed.) Everyday Language: Studies in Ethnomethodology (pp. 23-78). New York: Irvington.

Schegloff, E. A. (1980) Preliminaries to preliminaries: 'Can I ask you a question?'. Sociological Inquiry $50(3 / 4), 104-52$.

Schegloff, E. A. (1986) The Routine as achievement. Human Studies 9 (2/3), 111-51.

Schegloff, E. A. (1988) Pre-sequences and indirection: Applying speech act theory to ordinary conversation. Journal of Pragmatics 12 (1), 55-62.

Schegloff, E. A. and Sacks, H. (1973) Opening up closings. Semiotica 8 (4), 289-327.

Sell, R. D. (1992) Literary texts and diachronic aspects of politeness. In R. J. Watts, S. Ide and K. Ehlich (eds) Politeness in Language: Studies in its History, Theory and Practice. (Trends in Linguistics. Studies and Monographs 59), (pp. 109-29). Berlin, New York: Mouton de Gruyter.

Sifianou, M. (1995) Do we need to be silent to be extremely polite? Silence and FTAs. International Journal of Applied Linguistics 5 (1), 95-110.

Tulviste, T. (1995) Mothers' regulation of their two-year-olds' behavior in two settings. In K. Junefelt (ed.) Activity Theory. Proceedings of the XIVth Scandinavian Conference of Linguistics and the VIIIth Conference of Nordic and General Linguistics, 16-21 August 1993 (pp. 127-37). (Gothenburg Papers in Theoretical Linguistics 73). Gothenburg: Gothenburg University Press.

Tulviste, T. (1998) How much talk is expected from Estonian children. Trames 2 (1), $120-29$.

Vellerind, R. (2000) Lähendav viisakus müügivestluste strateegiana. Keel ja Kirjandus 48 (10), 703-15.

Wierzbicka, A. (1985) Different cultures, different languages, different speech acts. Polish vs. English. Journal of Pragmatics 9 (2), 145-58. 